\title{
IS DIGITAL 'NEW NORMAL' OR 'CHALLENGE' FOR BANKS UNDER COVID-19?
}

\author{
Nataliia VERSAL (), Vasyl ERASTOV ${ }^{\circledR}$, Mariia BALYTSKA \\ Insurance, Banking and Risk-Management Department, Economic Faculty, \\ Taras Shevchenko National University of Kyiv, Vasylkivska, 90 A, 03022 Kyiv, Ukraine
}

Received 28 February 2021; accepted 01 April 2021

\begin{abstract}
Purpose - to reveal prerequisites of technology-enabled banking development in Lithuania, Poland, and Ukraine; to identify if digitalization was a beneficial factor in households deposits-raising during the COVID-19.

Research methodology is twofold: analysis of digitalization index based on World Bank data as a premise of technology-enabled banks development; beta-coefficient analysis and descriptive statistics - for digitalization influence assessment.

Findings - digitalization index analysis showed that Lithuania has a more generous benefit in terms of digitalization. Poland and Ukraine follow with a slight gap. Traditional banks of analyzed countries are acting towards digitalization but at different paces. There are both digital and neobanks in Lithuania and Poland, while in Ukraine only digital banks. Analysis of Ukrainian banks deposits highlighted the fact that digital banks were in some cases more preferable for households, especially during a pandemic.

Research limitations - lack of data: common digitalization indexes could not be calculated for Ukraine; differences in countries' banking data: content and structuring criteria.

Practical implications - the results could be important for policy recommendations to tackle the blind spots of banking digitalization.

Originality/Value - suggested digitalization index could be utilized as a universal. Due to DESI limitations, common for EU countries, we were to create our own index and compare results with calculated by European Commission DESI values. While DESI is calculated using some specific survey data, the proposed index is using standardized data of World Bank; the results of digital and traditional banks deposits comparison could be useful for further study.
\end{abstract}

Keywords: digital banks, neobanks, digitalization index, household deposits, COVID-19.

JEL Classification: F65, G21, O33.

Conference topic: Contemporary Financial Management.

\section{Introduction}

Banks have existed for centuries; nevertheless, a study of their development history shows that they tend to be conservative institutions for a long time. However, the late 20th and early 21 st centuries were accompanied by unprecedented changes in the banking industry comparable to the late 19th and early 20th centuries' industrial revolutions. Banking has been developing extremely dynamically nowadays: developing specialized financial instruments (shadow banking), creating technologies to promote banking products and banking management.

Of course, digitalization affects all industries, but financial markets and especially banking institutions can show one of the greatest responses and beneficial results. Digitalization breaks established patterns of doing business and a gamechanger for both parties - customers and service providers. According to Gartner, digitalization is considered as digital technology utilization to change existing business models drastically and to provide new sources of revenue gaining (Gartner, n.d.). Digitalization can have major implications on data management, customer relationship, geographical presence, competition, employment, etc. Digital technologies in banking will provide many new opportunities, but the question is quite rhetorical "but at what price?".

\footnotetext{
*E-mail: natalia_versal@knu.ua
}

(C) 2021 Authors. Published by Vilnius Gediminas Technical University. This is an open-access article distributed under the terms of the Creative Commons Attribution (http://creativecommons.org/licenses/by/4.0/) License, which permits unrestricted use, distribution, and reproduction in any medium, provided the original author and source are credited. 
In the banking industry, a digital vision is being formed very quickly, not only in digital banks (neobanks or virtual banks) but also in traditional banks. For example, TBI Bank in Bulgaria has a very symbolic slogan, "Digitalization is our daily mission". But of course, in addition to the vision, there must be prerequisites and digitalization drivers, which are the quality of the Internet, access to gadgets, and many other necessary conditions, which we will talk about. It is undoubtedly vital to cultivate digital culture and even to promote digital culture, which, in fact, was greatly facilitated by COVID-19, when the demand for remote banking services increased and the cashless economy became an obvious reality.

Our study aims to reveal prerequisites of technology-enabled banking development in Lithuania, Poland, and Ukraine; to identify if digitalization was a beneficial factor in household deposits-raising during the COVID-19.

The paper is structured as follows: the first section reveals research methodology. The second section provides a literature review. The third section represents findings brocking into three blocks: firstly, we show prerequisites of technology-enabled banking development in Lithuania, Poland, and Ukraine using the Digital Economy and Society Index (DESI) and Digitalization index based on the World Bank Data. Secondly, we screen the situation with digital banks in analyzed countries. Thirdly, we identify if digitalization was a beneficial factor in household deposit-raising during the COVID-19 on the case of Ukrainian banks. In the fourth section, we conclude and provide an outlook on future research issues.

\section{Literature review}

Our study was based on an analysis of the digitalization effect on banks during a pandemic. But before evaluating the impact of digital transformation on banks' functioning, it is worth deciding what exactly it means. Some scientists note that digital transformation is a change in the business environment under the influence of a change in technology (Hess et al., 2016; Nadkarni \& Prügl, 2019). A slightly broader approach is used by Van Veldhoven and Vanthienen, who note that digitalization consists of a combination of three transformation areas: business, society, and technology (Van Veldhoven \& Vanthienen, 2019). If we talk about business transformation, then it implies, according to the authors, a change in business processes, the structure of the company, its relations with counterparties, the development of new products and business models. Technology transformation includes the implementation and improvement of companies' use of such digital innovations as IT, Internet, Advanced AI etc. Society transformation is the change that relates to customers, counterparties, and society. Such changes in values, priorities, habits, and principles of people occur from year to year and require appropriate reactions and adaptations from the business.

Morakanyane, O'Reilly, and Mcavoy identify the factors predetermining the success of the digital transformation. These factors have been divided into seven groups, among which, in the context of our research, it was necessary to turn into three: cultivate digital culture, develop digital vision, determine digital drivers (Morakanyane et al., 2020). According to Vial, digitalization is a transformational process, resulting in a challenge for organizations as they must change their strategic approach (Vial, 2019). Indeed, for banks, digitalization turns out to be a challenge that they initially did not accept. As a result, the skyrocketed fintech companies' development has led, without any particular difficulties, to gain a part in the payments market, loans, and deposits markets. These markets were traditionally assigned to banks. Banks have faced stronger competition in the households segment and in the corporations' segment, which indicates the crowdfunding platforms example.

It should be emphasized the positive impact of technology implementation on bank activities. On the one hand, banks will get more customers due to the utilization of digital channels for doing business, especially under the overall reach of the Internet. Lumpkin and Schich note that this trend of active development of digital banking, in addition to a more favorable pricing policy for customers, also brings customization of traditional products and services. Indeed, thanks to new technologies, banks are improving traditional services and offering new ones (Lumpkin \& Schich, 2020). Thus, Sharma and Kansal emphasize that implementing new solutions, such as self-inquiry facility, remote banking, anytime banking, telebanking, electronic banking, has become obvious advantages for clients of banking sector digitalization. In addition to customers benefiting from digitalization, a significant improvement of the bank's internal processes appears. Such improvement is possible due to new technologies, which will lead to benefits that the bank and its employees can feel (Sharma \& Kansal, 2014).

On the other hand, there will be greater competition due to vanishing geographical barriers and providing services even across the borders. Managing data streams will supply banks with new tools for providing individual and personalized services. However, it will be a lack of trust and personal privacy issues due to different legislative norms and requirements. And the last but not the least threat is the digitalization footprint on employment rates due to decreasing necessity of personnel involvement (and again, we can recall the industrial revolutions). All of the above-mentioned factors caused by digitalization are different in their influence.

Digitalization in itself does not affect banks' profitability, but at the same time, banks must clearly understand that digitalization is innovation, it is increasing competition, and of course, increasing risks, for which they need to be prepared (Niemand et al., 2020). Actually, the issues of cybersecurity today can be considered as the main threat 
of digitalization. According to a report from cybersecurity firm McAfee, "the monetary cost of cybercrime at around $\$ 945$ billion, or just over $1 \%$ of global gross domestic product (GDP)... With global spending on cybersecurity expected to exceed $\$ 145$ billion in 2020, cybercrime is now a 1 trillion dollar drag on the global economy" (Smith et al., 2020).

Advantages of banking industry digital transformation in the face of various shocks should be assessed using different approaches. In particular, the COVID-19 pandemic has shaken the global health system and the banking sector as a result. Such a crisis significantly differs from the usual crises since it is an exclusively exogenous shock for the economy, so all participants in the economy suffer drastic losses: both lenders and borrowers (Hasan et al., 2021). Accordingly, the tools that help banks reduce the impact of the crisis, this time differ from the traditional ones because of digitalization. Thus, the study of Digital Banking Maturity 2020, carried out by Deloitte specialists, notes the significant competitive advantages that banks receive due to actively using technology in their activities. Among the main benefits are lower cost-to-income ratios and higher return on equity. Banks that have already dynamically launched digital technology are much more responsive to new trends and challenges than traditional banks (Wodzicki et al., 2020).

Accenture's 2020 Global Banking Consumer Study, based on a survey of 47,000 consumers worldwide, notes the lack of human factors in banking due to global digitalization, which undermines customer confidence in these financial institutions. In this regard, the banks have been advised to take a balanced approach to digitalization, moderately combining digital technology and human interaction when working with customers (Mcintyre et al., 2020).

\section{Methodology}

Economic development is a multilateral phenomenon that is caused by both historical and international aspects. Nowadays, the economy is highly integrated and interconnected. Such economic relationships greatly influence any part of the entire system, and its footprint can be both positive and negative. Any system could be divided into a set of subsystems or blocks with some technics of decomposition. While decomposing the economic system, there could be found some independent elements that represent different types of activities. One of them is the financial system, which can also be decomposed into banking, insurance, etc. All of the mentioned elements are independent and integrated at the same time. Banking, for example, is one of the most known and developed parts of it.

Contrariwise, one of the deepest interrelations and integration aspects for each and every economic interaction level is digitalization. And all of the decomposed elements are getting benefits and threats from digitalization, but will it help under unpredictable external influences? COVID 19 pandemic, for example.

Digitalization level can be estimated, but not all of existing methods and models could be used for some countries. For example, DESI is common for all European Union countries, but it could not be used for almost any other country. DESI is a composite index based on relevant indicators of EU digital performance and evolution. It is calculated from a set of indicators that are aggregated into five dimensions: connectivity, human capital, use of the Internet, integration of digital technology, and digital public services. Some of them are not available for non-European countries because they are estimated via expert methods or surveys held only for member countries. Thus, the connectivity dimension is calculated from extended statistics of internet and mobile network prices, the number of users, and connection speed. It also involves some indicators like $5 \mathrm{G}$ readiness based only on an assigned spectrum and can differ due to technologies and legislation. The human capital dimension is based on surveys and the concept of "basic" digital skills, though it is based on employees' understanding of this concept and cannot be used in other countries with different education systems. The use of the Internet dimension is also based on surveys held for households and individuals, but in most cases limiting the age of respondents from 16 to 74, while in some cases, both limitations are irrelevant due to life expectancy and younger groups' internet activity. Integration of digital technology dimension is also based on surveys data, but also involves such indexes like "Social media" and "Cloud" as raw data, while it should be mentioned that there are legislative and industry limitations influencing these indexes. The last dimension, digital public services, is based on eGovernment Benchmark, designed for EU countries, and survey, which is again limiting estimation of these index set to European countries (see equation 1) (Digital Economy and Society Index [DESI], n.d.).

$$
\begin{aligned}
& \text { DESI }=\text { Connectivity } * 0.25+\text { Human_Capital } * 0.25+\text { Use_of_Internet } * 0.15+ \\
& \text { Integration_of_Digital_Technology } * 0.2+\text { Digital_Public_Servises } * 0.15 .
\end{aligned}
$$

While the DESI is not suitable for some countries, it was proposed a simplified approach based on available information and statistics. World Bank statistics provides all indicators. This source was chosen due to its availability worldwide and provides information about the vast majority of countries. Also, DESI was designed to evaluate the overall digitalization level, while it was necessary to understand and compare the impact on the banking industry.

It was proposed to use three sets of indicators to describe different dimensions, like banking readiness, population aspect, and infrastructural readiness. To evaluate the first dimension, it was considered to use two indicators: automat- 
ed teller machines and commercial bank branches, both per 100000 adults. These indicators should show banks and society's readiness to increase the amount of digitally-driven operations instead of going to a physical bank branch or using cash. This dimension also has some limitations caused by the historical and economic environment, but data is highly available and could be normalized by additional indexes. The population aspect diagnostic was chosen three indexes like employment to population ratio, population density, and 15-64 years old population share. Mentioned set of indicators should provide information about overall potential customers of banking services, especially digital. This set can also be considered limited, but it reflects the main part of potential users who will adopt digital service. However, it could be extended via additional indexes. The last dimension consists of five indicators: share of Internet users in the overall population; the amount of secure Internet servers per 1 million people; mobile cellular, fixed telephone, and fixed broadband subscriptions per 100 people. This set of indexes is expected to show the main infrastructure readiness in terms of both stable and high-speed Internet access availability and Internet security orientation. This set is not comprehensive but is able to provide a sufficient amount of data for estimation.

For evaluation of banking digitalization level with mentioned set of indicators was proposed respective methodology. Every index is scored from 0 to 50, depending on the distribution of raw data. To normalize the distribution of indexes, geometric progression was used with precalculated ratio (see Equation (2)).

$$
q=\sqrt[n-1]{\frac{b_{n}}{b_{1}}}
$$

where: $q$ - ratio of geometric progression; $b_{1}-$ minimal index value in period, $b_{n}-$ maximal index value in period, $n$ - scores quantity.

To get the set of scoring intervals we used simple geometric sequence with ratio $\mathrm{q}$ and minimal index value in period as an initial value (see Equation (3)).

$$
b_{1}, b_{1} q, b_{1} q^{2}, b_{1} q^{3} \ldots b_{1} q^{n-1}
$$

where: $q$ - ratio of geometric progression; $b_{1}$ - minimal index value in period, $n$ - scores quantity.

To get scores we used Python script, that is comparing the value of country index with the set of index intervals and returning the score (see Figure 1).

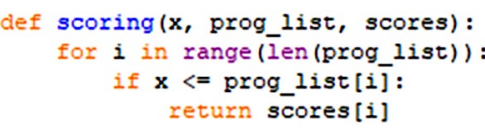

where: $x$ - country index value; prog_list - normalized index intervals, scores - set of scores.

Figure 1. Python scoring function

After getting scores for each index, the overall score should be calculated simply by summing each individual value and dividing by the number of used indexes (see Equation (4)). The final index value will be in 0-50 interval, just like each individual index. The proposed evaluation methodology can be changed by modification of scores and number of groups for comparison. By decreasing group number, the final estimation can be simplified for faster results, but this change will decrease the evaluation precision. By increasing the number of groups, up to overall countries number, it is possible to get more accurate and precise ratings, but the amount of calculations will increase drastically.

$$
\text { Digitalization Index }=\sum_{i=1}^{10} X_{i} \text { Score } / 10,
$$

where: $X_{i}$ Score - each individual score of countries indicators.

We differentiate between traditional banks, which provide services exclusively through physical branches, and a new group of banks - technology-enabled banks. These banks use technologies in their work, diversifying interaction channels with the client (digital bank) or moving completely to the online space (virtual bank or neobank). Since the study focuses on the digital banks of Ukraine, several features should be noted. In Ukraine, a high level of dollarization of deposits of individuals remains, over $40 \%$. This is due to many factors, but first of all - distrust of the national currency. The purchase of foreign currency by households was strictly regulated; however, there have been major changes due to currency liberalization. In particular, in Ukraine in February 2019, individuals were allowed to purchase foreign currency in a non-cash form. That is why the study focuses on analyzing four indicators: on-demand deposits in national currency and foreign currency, term deposits in national and foreign currency.

The study period $01.01 .19-01.12 .20$ covers two periods: the period before the pandemic $(01.01 .19-01.02 .20)$ and the period of the pandemic, which begins with the going into the first lockdown in Ukraine from 18 March 2020 $(01.03 .20-01.12 .20)$. It should be noted that there is a floating exchange rate in Ukraine, and the period under study covers both revaluation and devaluation of the national currency. The devaluation amounted to $15.1 \%$ for the period 
01.10.19-01.12.20. This necessitated presenting deposits in foreign currency in US dollar equivalent. The US dollar was chosen because household deposits in foreign currency are mostly represented in US dollars; namely, during the study period, the share of US dollar deposits in the total volume of foreign currency deposits averaged $84 \%$.

For the analysis of the indicated indicators, beta-coefficient was chosen. Based on this indicator's calculation, it is possible to determine sensitivity in changing of deposits of one bank to movements in the overall deposit market.

$$
\beta=\frac{\text { Covariance }(\text { Change in deposits of bank,Change in deposit market })}{\text { Variance }(\text { Change in deposit market })} \text {. }
$$

So, firstly we calculate and analyze beta-coefficients in four segments: On-demand deposits in local currency and foreign currency and term deposits in local currency and foreign currency. Secondly, we provide results of descriptive statistics in the same segments for digital and traditional banks. We assume the banks that are leaders in the use and development of digital solutions should be better positioned during the pandemic. The analysis was carried out in the sample: 45 banks out of 74 operating in Ukraine as of 01.12 .20 account for more than $98 \%$ of funds on households' accounts. The rest of the banks were excluded from the sample due to: liquidation during the analyzed period, focus on the corporate sector, and unusual activities that are very vulnerable in the deposits market.

\section{Findings and discussion}

\subsection{Digitalization as a key factor of technology-enabled banking development}

Due to this limitation, we can use DESI comparison only for Poland and Lithuania. To understand the digitalization trend in selected countries was estimated for 6 years and consolidated in Table 1. According to the DESI methodology and publication sequence year values represents previous year data.

Table 1. DESI comparison of Lithuania and Poland in 2015-2020 (source: DESI, n.d.)

\begin{tabular}{|l|c|c|c|c|c|c|}
\hline Years & 2015 & 2016 & 2017 & 2018 & 2019 & 2020 \\
\hline Poland & 31,30625 & 32,52601 & 35,51729 & 37,67146 & 40,72039 & 44,95923 \\
\hline Lithuania & 40,37273 & 42,51162 & 45,00655 & 49,35771 & 51,80269 & 53,88716 \\
\hline
\end{tabular}

Lithuania shows a higher level of DESI all over the research period. By the end of the 2020 estimation, Poland has reached the 2017 Lithuania level. Nevertheless, both countries show a significant growth trend. Each of the DESI dimensions was growing from year to year, showing constant improvement in underlying indexes. To understand and describe such differences in DESI level, decomposed representation was provided for the 2020 (see Figure 2).

Exploring the DESI dimensions level, it could be mentioned almost similar connectivity level, representing an overall state of infrastructure. The relatively low difference could be found in human capital and use of Internet services that are partially caused by the difference in population amount and historical aspects. The biggest difference is in the integration of digital technology dimension. This could be explained by longer EU integration, peculiarities of main activity fields, and overall growth trend.

After DESI evaluation that showed a significant difference in digitalization level between Poland and Lithuania, it is necessary to compare it with the proposed methodology. Also, there will be an opportunity to compare Ukraine with two EU countries in terms of banking digitalization.

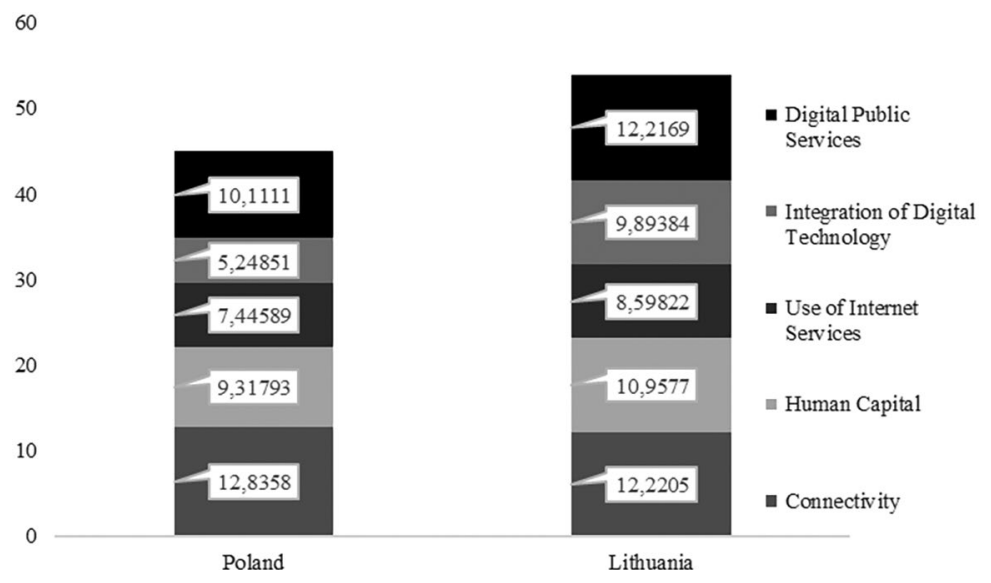

Figure 2. Decomposed 2020 DESI value for Lithuania and Poland (source: DESI, n.d.) 
Comparing the total value of estimated digitalization level in Lithuania, Poland, and Ukraine and DESI values proved that Lithuania has a higher level. Also, it should be mentioned that the growth trend is also observed. Thus, the proposed methodology is accurate enough. Comparing the set of chosen countries, it should be highlighted that Poland has the lowest digitalization level. Ukraine, as a newbie for this comparison, showed significant growth from the beginning of our observation. Ukraine got a confident better hand over Poland. Differences in growth rates in each period are caused by changes in legislation and policy that affected the banking industry. Returning to Lithuania values, constant growth in line with significant superiority in terms of digitalization level could be observed. This alignment of countries showed some beneficial role of globalization and overall stable economic situation. Ukraine keeps pace with EU countries due to the implementation of best practices and the search for new opportunities (see Table 2).

Table 2. Calculated 2013-2019 indexes for Lithuania, Poland and Ukraine (source: World Bank, n.d.)

\begin{tabular}{|l|c|c|c|c|c|c|c|}
\hline \multicolumn{1}{|c|}{ Countries } & 2013 & 2014 & 2015 & 2016 & 2017 & 2018 & 2019 \\
\hline Lithuania & 27.9 & 28.5 & 28.5 & 29.3 & 28.9 & 29 & 29.7 \\
\hline Poland & 26.8 & 27.2 & 26.7 & 27.2 & 26.4 & 26.6 & 26.9 \\
\hline Ukraine & 27.8 & 28.7 & 28.7 & 29.6 & 28.7 & 28.6 & 29.3 \\
\hline
\end{tabular}

\subsection{Technology-enabled banking expansion in Lithuania, Poland, and Ukraine}

The rapid development of technology has created favorable conditions for improving the functioning of various sectors of the economy, the banking sector in particular. Evidence of the active digitalization of banking is the development of Internet banking. Digitalization allows banks to carry out almost all transactions online, via the Internet. Before the pandemic, customer identification remained unresolved or partially unresolved, which was successfully implemented during COVID-19 using videoconferencing programs.

Two main reasons can help explain the growing popularity of Internet banking: first, it is becoming easier and more comfortable for customers to use the Internet to obtain banking services, and second, it is growing the Internet banking security. Other reasons for the growing popularity of Internet banking are the greater public confidence in doing business over the Internet, low cost of access and use of Internet banking, and lower costs for banks associated with the introduction of Internet banking.

Despite the spread of Internet banking, banks have faced many obstacles to its implementation because any new technology opens up new opportunities but must overcome the challenges. There are as follows: the incompatibility of hardware and software under the mergers and acquisitions of banks, cumbersome information technology infrastructures that limit product supply and constrain effective customer relationship management, and high technological costs that hinder the development and implementation of improved systems. However, technology's introduction makes it much easier to work in the financial services sector (Prykaziuk et al., 2019).

Increased competitiveness of banks positively impacts customer service delivery due to the implementation of advanced services and technologies. Internet banking is the most cost-effective and reasonable approach to remote interaction with customers, along with traditional ATMs and self-service terminals. Given the reduction in the bank's operating and other expenses, the commission for services provided via the Internet is also reduced, making recourse to the physical branch economically unreasonable.

Given how banks use technology in their activities, it is possible to classify banks in some groups (see Figure 3).

The traditional bank mainly works through physical branches. The involvement of technologies turns it into a digital bank. Digital banks are deposit-taking institutions that are members of a deposit insurance scheme and sell their services both through physical branches and through online communication channels (Ehrentraud et al., 2020).

Also, could be other grounds for banks to be considered digital: 'commitment to innovation with a modernized data center; embrace of cloud technologies to create a platform for rapid growth; optimization of bank branches to be relevant in the digital age; personalization of customer experiences; adoption of a security-first approach - from data centers to devices' (VMware, 2021).

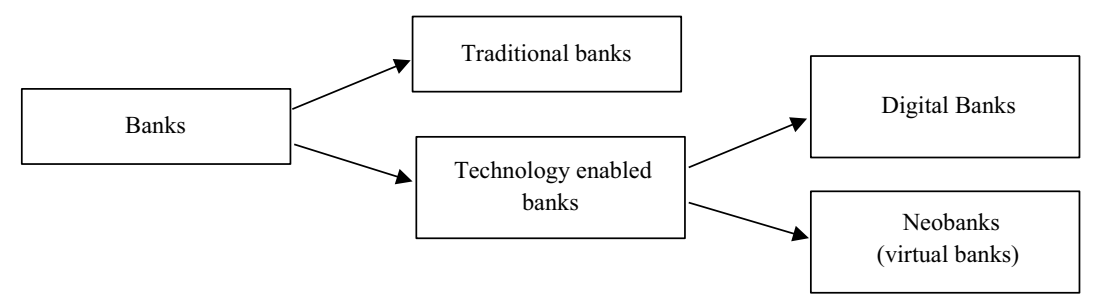

Figure 3. Classification of banks (source: authors' development based on Ehrentraud et al., 2020) 
However, a digital bank is only a transitional stage between traditional and virtual banks. According to the main characteristics of neobank, its main difference from the digital bank the lack of traditional branch infrastructure. Neobank provides banking and payment services exclusively within the Internet. Typically, neobank's services include issuing classic or virtual payment cards, mobile/virtual deposits, individual payments using phone numbers, emails, or social media profiles as an identifier, mobile and virtual budgeting tools, and real-time digital receipts. Due to the reduced operating costs, neobanks can often offer higher interest rates, lower fees for servicing card accounts, and a high level of customer support and interaction.

The share of Internet banking users is growing all over the world, and in particular in Ukraine, Poland, and Lithuania. In Ukraine, the digital sphere is actively developing; thus, traditional banks are gradually improving their own operational processes, offering customers the benefits of Internet banking. At the end of 2020, 74 commercial banks functioned in Ukraine (National Bank of Ukraine, 2021a). The most popular in online banking services are the following banks: JSC “Oschadbank”, PJSC CB PRIVATBANK, PJSC “UNIVERSAL BANK”, PJSC “ALFA-BANK”, JSC “Credit Agricole Bank", PJSC "FUIB”. Many other traditional banks invest heavily in digitalization as well. Still, it is too early to call them confident players in the digital banking market.

In Ukraine, the best digital startup in recent years was Monobank, developed as a stand-alone product concept but was launched on the traditional bank Universal Bank. As a result, Universal Bank became the status of the digital bank. Monobank banking services allow to use and service current accounts, payments of various types with low or without fees, open deposits, and receive other services remotely, through smartphones. Since the official release of the Monobank in November 2017, 3 million customers have joined the project in three years (Monobank, 2020).

In Lithuania, at the end of 2020, existed 17 banks (Bank of Lithuania, 2021). The banking digitalization in Lithuania has also developed very active. In general, the country's regulatory authorities have created a fairly favorable environment for introducing financial technologies (SBSB Fintech Lawyers, 2021). Lithuania has been a full member of the EU since 2004, so its banking license is recognized in all EU countries (The Lithuania Tribune, 2021). Also, Lithuania offers a competitive tax framework. The corporate income tax rate is from $0 \%$ to $15 \%$ and is the third-lowest rate in the EU, and the personal income tax rate - 15\% - the second in the same ranking (InvestLithuania, 2018). These additions have made it possible to neobank startup - Revolut in 2018 started its work as a licensed bank in Lithuania in 2018 (Fintech Futures, 2021), and in 2019 it was the largest neobank in Europe based on the number of customers involved (NeoBanks.App, 2021a, 2021b). In addition to Revolut, six other neobanks existed in Lithuania (see Table 3).

Table 3. Characteristics of neobanks that can provide their services in Lithuania and Poland (source: NeoBanks.App, 2021a, 2021b)

\begin{tabular}{|l|l|c|c|}
\hline \multirow{2}{*}{ Neobank } & \multicolumn{2}{c|}{$\begin{array}{c}\text { Country with } \\
\text { Head office }\end{array}$} & \multicolumn{2}{c|}{ Presence in country } \\
\cline { 3 - 4 } & & Lithuania & Poland \\
\hline Vialet & Lithuania & + & + \\
\hline Bunq & Netherlands & + & + \\
\hline Curve & Great Britain & + & + \\
\hline TransferWife & Great Britain & + & + \\
\hline Monese & Great Britain & + & + \\
\hline Revolut & Great Britain & + & + \\
\hline Bitwala & Germany & + & + \\
\hline Nest Bank & Poland & - & + \\
\hline mBank & Poland & - & + \\
\hline N26 & Germany & - & + \\
\hline
\end{tabular}

The Polish banking system consists of 37 commercial banks, 532 cooperative banks, and 31 branches of foreign banks at the end of 2020. Except for four relatively small mortgage banks and other small specialized banks, most banks provide universal banking services. The emergence of neobanks and growing competition forces them to focus more on online banking. Two apparent leaders in online banking are ING Bank Śląski (Stephie, 2019) and PKO Bank Polski, which has been recognized due to the world's best digital mobile banking application for the past two years (Shan, 2019). In addition to traditional banks, there are also ten full-fledged neobanks in Poland (see Table 3).

\subsection{Digital banks on deposit market under COVID-19: case of Ukraine}

At first glance, banks offering optimal digital solutions should be more competitive than traditional banks, especially in the households segment. This is confirmed by the fact that the digitalization level in Ukraine increased significantly over the past five years. The COVID-19 pandemic was supposed to accelerate these trends. The demand for cashless 
payments and contactless payments increased significantly. Thus, in the first nine months of 2020, cashless payments and cash withdrawals increased in number by $18.0 \%$ and in value by $8.7 \%$ compared to the same period of 2019 (National Bank of Ukraine, 2021b). Banks that are leaders in payment cards issuing and in digitalization in Ukraine are JSC "Oschadbank" (government bank), PJSC CB PRIVATBANK (government bank), PJSC "UNIVERSAL BANK" (private bank with local capital), PJSC "ALFA-BANK" (a private bank with foreign capital), JSC "Credit Agricole Bank" (a private bank with foreign capital), PJSC "FUIB" (a private bank with local capital). Simultaneously, the results do not always support their pronounced benefits due to digitalization when analyzing on-demand deposits and term deposits of households.

On-demand deposits in local currency. Analysis of the beta coefficient allows us to note that in the non-pandemic period, digital banks (highlighted rectangle) had not more benefits in the on-demand deposit market than other banks. It means that other factors influenced households choice of a bank (in particular, the bank's size, its form of ownership (government, private foreign), and the banks' interest rates.

During the pandemic, digital banks' role increased; however, some banks developed much more actively, particularly small banks (see Figure 4). We have calculated beta-coefficient for every bank from our sample before the pandemic period (one year, monthly data) and in the pandemic period. We have got such results: in non-pandemic period (NPP) beta-coefficient was for Oschadbank 0.80 and in pandemic period (PP) 1.65, PRIVATBANK - 0.95 in NPP, 0.71 in PP, UNIVERSAL BANK - 0.95 in NPP, 0.65 in PP, ALFA-BANK - (Ukraine) 0.35 in NPP, 0.80 in PP, Credit Agricole Bank (Ukraine) 1.57 in NPP, 1.34 in PP, FUIB - 1.18 in NPP, 1.06 in PP. So, in the pandemic period, not all digital banks got the possibility to grow more than the market.

In the non-pandemic period, the average growth rates of on-demand deposits in the national currency of digital banks significantly exceeded other banks' average growth rates. During the pandemic, this gap narrowed significantly. If we evaluate the standard deviation, it is evident that it was higher in digital banks than in other banks in pandemic and non-pandemic periods. The same situation is with range. As for the minimum values of growth rates, among the digital banks, there were two banks, where the fall in on-demand deposits in the pandemic period was minimal (PJSC CB PRIVATBANK - 0.008) or there was no fall (PJSC "UNIVERSAL BANK" - 0.039). Assessing the maximum values of on-demand deposit growth rates, we note that during the non-pandemic period, digital banks had indicators that in most cases significantly exceeded the growth rates in other banks. And during the pandemic, digital banks did not have such a significant advantage (see Table 4). Thus, digitalization was not the main factor that household depositors considered when considering on-demand deposit making.

On-demand deposits in foreign currency. On-demand deposits in foreign currency have the peculiarity that, in most cases, they are used by households more for savings than for settlements. The beta coefficients in digital banks were in non-pandemic period (NPP) for Oschadbank 0.77 and in pandemic period (PP) 1.11, PRIVATBANK - 1.16 in NPP, 0.62 in PP, UNIVERSAL BANK - 0.93 in NPP, 2.59 in PP, ALFA-BANK - (Ukraine) 1.53 in NPP, 0.25 in PP, Credit Agricole Bank (Ukraine) 0.27 in NPP, 0.67 in PP, FUIB - 0.48 in NPP, 0.63 in PP. So, in the pandemic period, not all digital banks grew more than the market (see Figure 5). It can be attributed to several factors. Firstly, some of the digital banks benefited significantly during the non-pandemic period since it was allowed to buy currency online at that time. Hence, banks grew faster than the market. Secondly, during the pandemic period, two factors worked at once: an increase in savings in foreign currency, which was due to devaluation and inflation expectations, and also need to have such savings in the most liquid form. The last requirement is met precisely by on-demand deposits in foreign currency. Thirdly, the interest rate on such deposits is also an important factor. There was a significant inflow of such deposits in PJSC "UNIVERSAL BANK", since this bank offered rates higher than the market average.
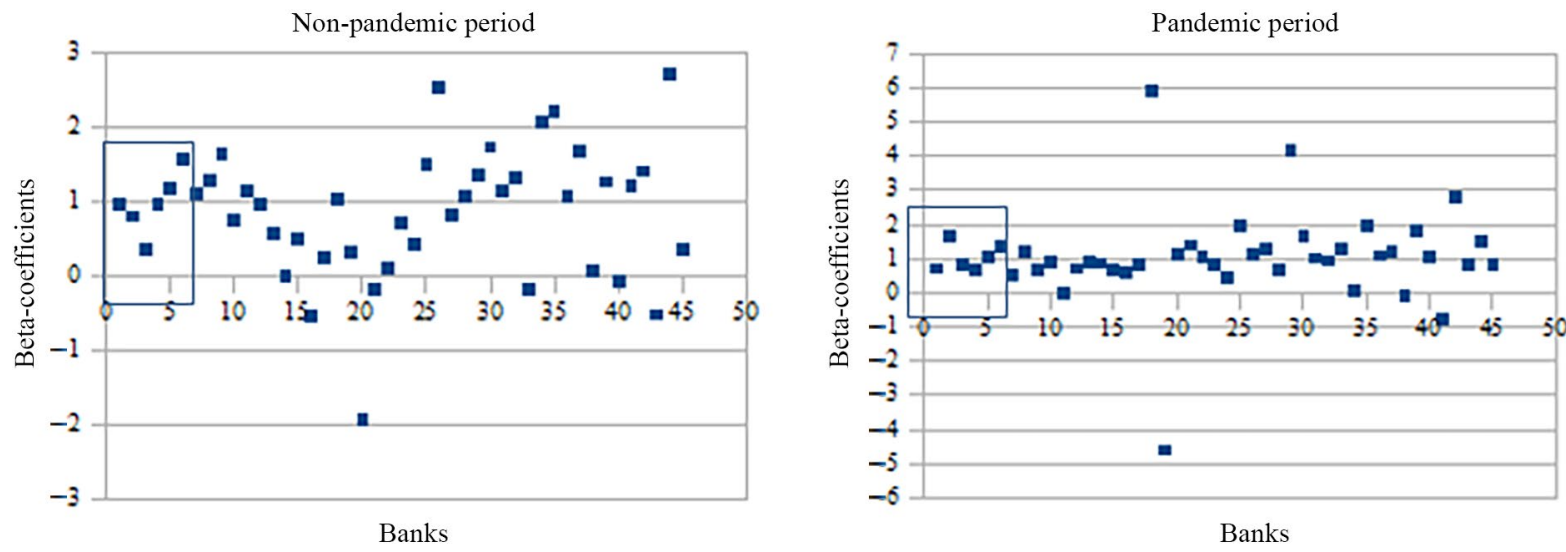

Figure 4. Beta-coefficients of on-demand deposits in local currency of Ukrainian banks for non-pandemic (01.01.2019-01.02.2020) and pandemic (01.03.2020-01.12.2020) periods (source: authors' calculations based on National Bank of Ukraine, 2021a) 
The average growth rate of on-demand deposits in foreign currency changed compared to the non-pandemic period, mostly in digital banks; in many cases, it was positive. The volatility of the growth rate of on-demand deposits in foreign currency, measured by the standard deviation, indicates that it has increased more in other banks than in digital banks when comparing the non-pandemic and pandemic periods. As for other characteristics, the special position of PJSC "UNIVERSAL BANK" is clearly visible, which not only had not a fall in on-demand deposits in foreign currency, but also the maximum values in both non-pandemic and pandemic periods significantly exceed the values in other banks and amount to 0.262 in non-pandemic, and 0.386 in pandemic periods (see Table 5).

Term deposits in local currency. Term deposits in national currency are a direct instrument for household savings. This means that besides considering such a factor as a convenience (digital convenience), the bank's reliability also plays a vital role. Research in this area shows that in Ukraine, households prefer state-owned banks and banks with foreign capital (Versal, 2019). These segments mostly represent many digital banks in Ukraine. Accordingly, these banks were in a fairly good position during the pandemic. The values of the beta coefficient in some of the most developed digital banks had two or even three times excess in both non-pandemic and pandemic periods (digital banks are shown in the rectangle) (see Figure 6).

The data in Table 6 do not show any particular advantages of digital banks in the segment of term deposits in the local currency. During the pandemic period, most digital banks showed positive values of their average growth rates. And again, it is necessary to note PJSC "UNIVERSAL BANK", showing the maximum values of growth rates, which were several times higher than the values in other banks.

Term deposits in foreign currency. In contrast to the deposits discussed above, the term deposits in foreign currency showed negative dinamic during the pandemic. Above, we mentioned that under uncertainty, households turned such deposits into the most liquid form, including transformation into on-demand deposits. But in general, it is obvious that the volume of deposits in digital banks, on average, fell more slowly than the overall decline in the banking system (see Figure 7).

Table 4. Descriptive statistics of growth rate of on-demand deposits in local currency in digital banks and other banks from sample in non-pandemic (NPP) and pandemic periods (PP), Ukraine (source: authors' calculations based on the NBU Data)

\begin{tabular}{|c|c|c|c|c|c|c|c|}
\hline Banks & Period & Mean & St. Dev. & Range & Min & Max & Observations \\
\hline \multirow{2}{*}{$\begin{array}{l}\text { PJSC CB } \\
\text { PRIVATBANK }\end{array}$} & NPP & 0.019 & 0.051 & 0.215 & -0.056 & 0.159 & 13 \\
\hline & PP & 0.031 & 0.035 & 0.126 & -0.008 & 0.118 & 10 \\
\hline \multirow[t]{2}{*}{ JSC “Oschadbank” } & NPP & 0.018 & 0.042 & 0.152 & -0.056 & 0.097 & 13 \\
\hline & $\mathrm{PP}$ & 0.036 & 0.081 & 0.305 & -0.065 & 0.240 & 10 \\
\hline \multirow[t]{2}{*}{ PJSC “ALFA-BANK" } & NPP & 0.018 & 0.074 & 0.250 & -0.091 & 0.159 & 13 \\
\hline & PP & 0.036 & 0.099 & 0.335 & -0.110 & 0.224 & 10 \\
\hline \multirow[t]{2}{*}{ PJSC “FUIB” } & NPP & 0.028 & 0.077 & 0.264 & -0.073 & 0.191 & 13 \\
\hline & PP & 0.042 & 0.086 & 0.275 & -0.077 & 0.198 & 10 \\
\hline \multirow{2}{*}{$\begin{array}{l}\text { PJSC "UNIVERSAL } \\
\text { BANK" }\end{array}$} & NPP & 0.088 & 0.068 & 0.207 & -0.005 & 0.202 & 13 \\
\hline & $\mathrm{PP}$ & 0.095 & 0.052 & 0.178 & 0.039 & 0.217 & 10 \\
\hline \multirow{2}{*}{$\begin{array}{l}\text { JSC “CREDIT } \\
\text { AGRICOLE BANK” }\end{array}$} & NPP & 0.016 & 0.083 & 0.316 & -0.117 & 0.198 & 13 \\
\hline & PP & 0.038 & 0.048 & 0.162 & -0.030 & 0.132 & 10 \\
\hline \multirow[t]{2}{*}{ Other banks } & NPP & 0.007 & 0.065 & 0.208 & -0.098 & 0.110 & 13 \\
\hline & PP & 0.029 & 0.047 & 0.173 & -0.024 & 0.149 & 10 \\
\hline
\end{tabular}
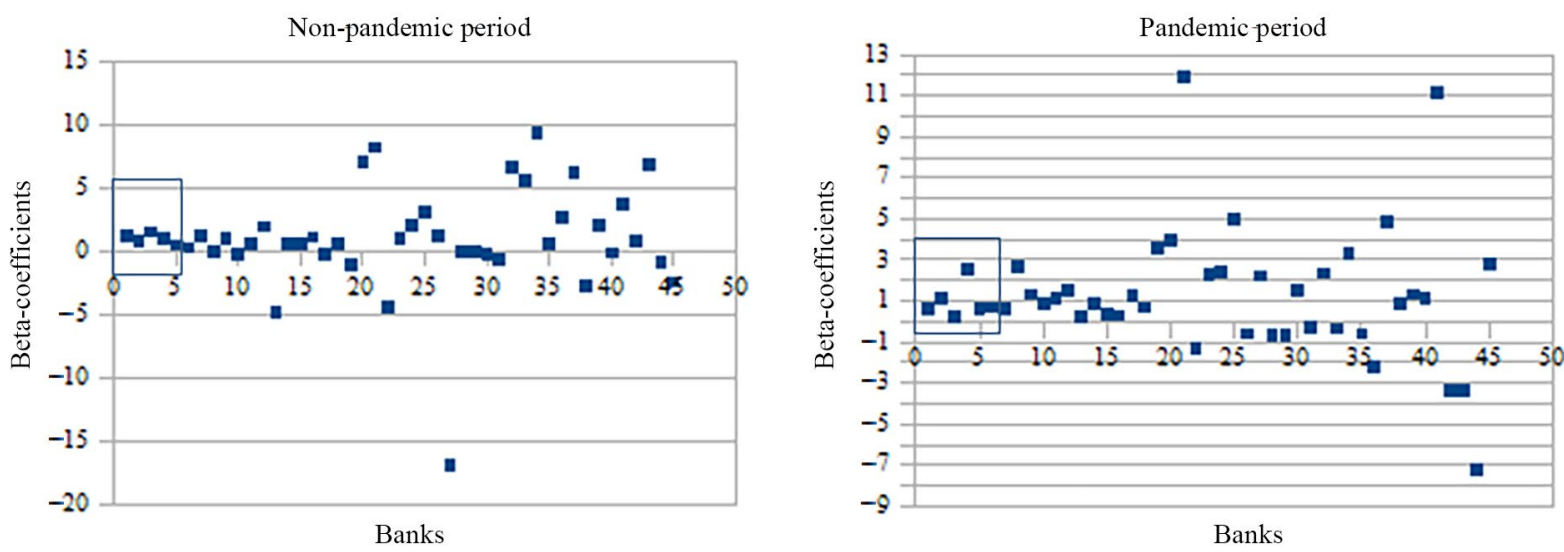

Figure 5. Beta-coefficients of on-demand deposits in foreign currency of Ukrainian banks for non-pandemic (01.01.2019-01.02.2020) and pandemic (01.03.2020-01.12.2020) periods (source: authors' calculations based on National Bank of Ukraine, 2021a) 
Simultaneously, if we evaluate descriptive statistics data, then, firstly, the average rate of decline of term deposits in foreign currency in digital banks, except Universal Bank, under pandemic was higher than in other banks. This can be explained by the ease of deposit withdrawal in digital banks, unlike other banks. Secondly, practically the same situation arose with the volatility, which is higher in most digital banks during a pandemic than in a non-pandemic period. And we also observed that Universal Bank, as before, is in a significantly better position than other banks, and this position is connected exclusively with its digital focus.
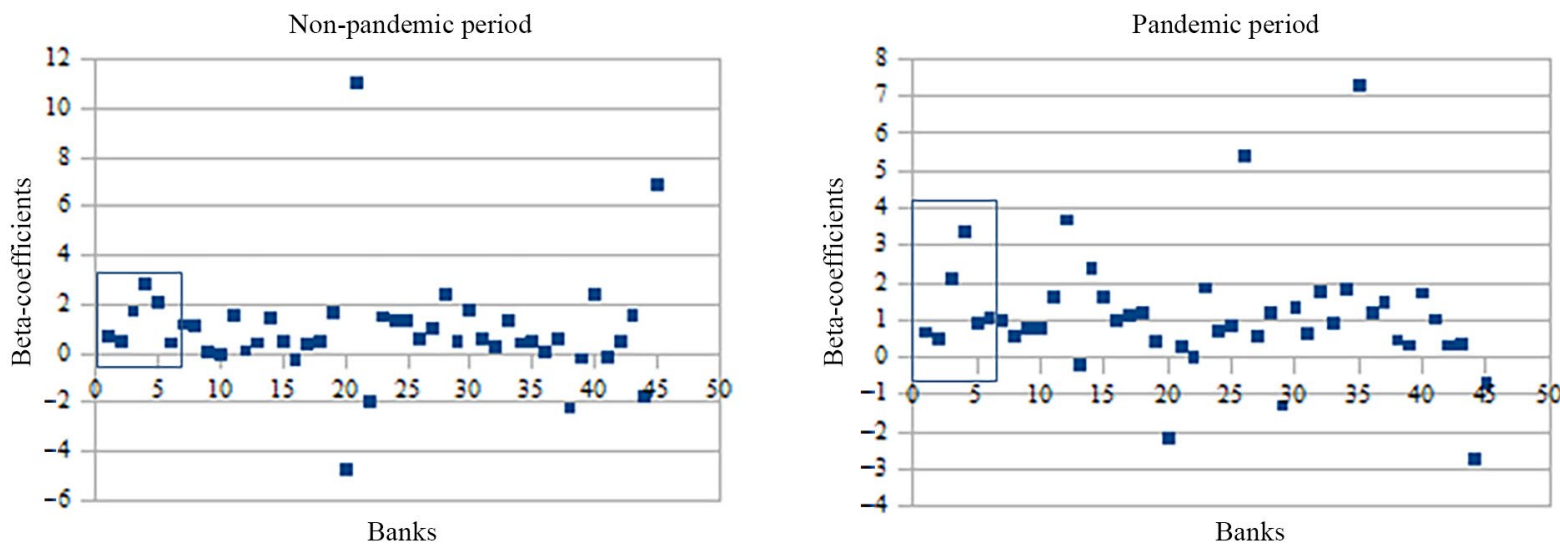

Figure 6. Beta-coefficients of term deposits in local currency of Ukrainian banks for non-pandemic (01.01.2019-01.02.2020) and pandemic (01.03.2020-01.12.2020) periods (source: authors' calculations based on National Bank of Ukraine, 2021a)

Table 6. Descriptive statistics of growth rate of term deposits in local currency in digital banks and other banks from sample in non-pandemic (NPP) and pandemic periods (PP), Ukraine (source: authors' calculations based on the NBU Data)

\begin{tabular}{|c|c|c|c|c|c|c|c|}
\hline Banks & Period & Mean & St. Dev. & Range & Min & Max & Observations \\
\hline \multirow[t]{2}{*}{ PJSC CB PRIVATBANK } & NPP & 0.006 & 0.010 & 0.037 & -0.014 & 0.023 & 13 \\
\hline & PP & 0.004 & 0.009 & 0.033 & -0.013 & 0.019 & 10 \\
\hline \multirow[t]{2}{*}{ JSC "Oschadbank" } & NPP & 0.007 & 0.006 & 0.019 & -0.001 & 0.018 & 13 \\
\hline & PP & 0.008 & 0.008 & 0.019 & -0.002 & 0.018 & 10 \\
\hline \multirow[t]{2}{*}{ PJSC “ALFA-BANK” } & NPP & 0.024 & 0.020 & 0.062 & 0.001 & 0.062 & 13 \\
\hline & PP & -0.005 & 0.029 & 0.087 & -0.038 & 0.048 & 10 \\
\hline \multirow[t]{2}{*}{ PJSC “FUIB” } & NPP & 0.039 & 0.024 & 0.077 & -0.006 & 0.071 & 13 \\
\hline & PP & 0.000 & 0.019 & 0.064 & -0.034 & 0.029 & 10 \\
\hline \multirow{2}{*}{$\begin{array}{l}\text { PJSC "UNIVERSAL } \\
\text { BANK" }\end{array}$} & NPP & 0.096 & 0.038 & 0.119 & 0.049 & 0.168 & 13 \\
\hline & PP & 0.034 & 0.051 & 0.170 & -0.012 & 0.158 & 10 \\
\hline \multirow{2}{*}{$\begin{array}{l}\text { JSC “CREDIT } \\
\text { AGRICOLE BANK” }\end{array}$} & NPP & 0.049 & 0.024 & 0.079 & 0.009 & 0.088 & 13 \\
\hline & $\mathrm{PP}$ & -0.014 & 0.033 & 0.122 & -0.084 & 0.038 & 10 \\
\hline \multirow[t]{2}{*}{ Other banks } & NPP & 0.014 & 0.014 & 0.043 & 0.000 & 0.043 & 13 \\
\hline & PP & -0.003 & 0.016 & 0.054 & -0.030 & 0.024 & 10 \\
\hline
\end{tabular}
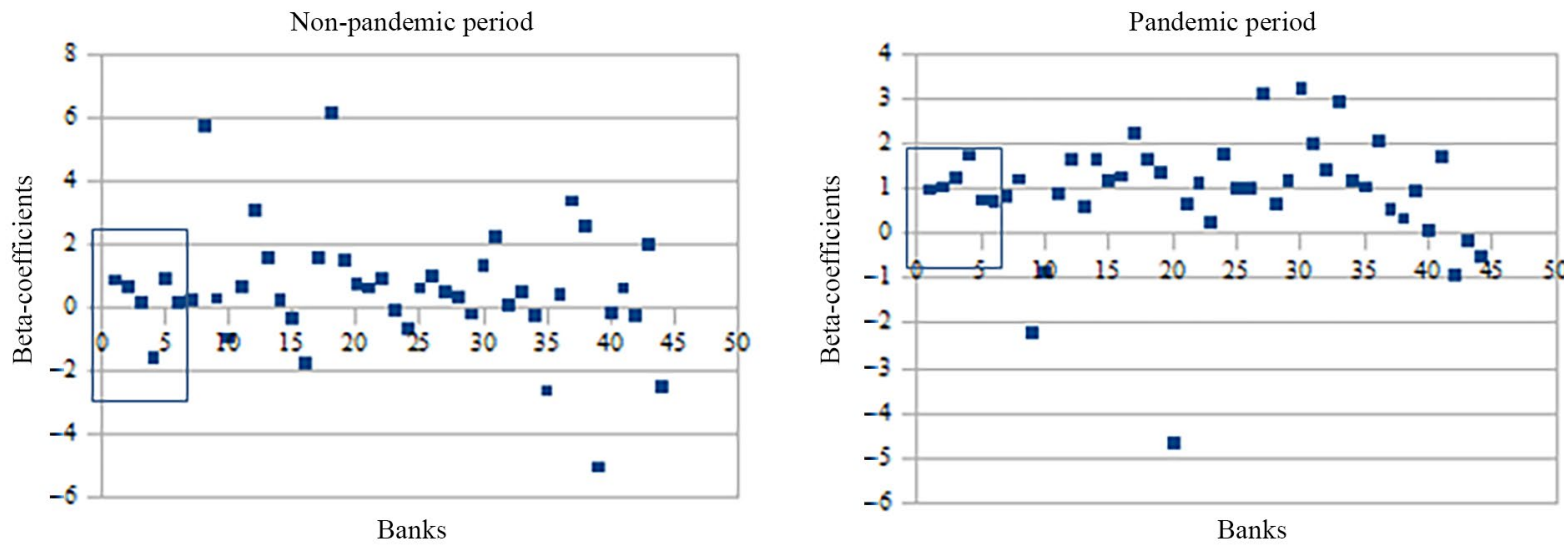

Figure 7. Beta-coefficients of term deposits in foreign currency Ukrainian banks for non-pandemic (01.01.2019-01.02.2020) and pandemic (01.03.2020-01.12.2020) periods (source: authors' calculations based on National Bank of Ukraine, 2021a) 
Table 7. Descriptive statistics of growth rate of term deposits in foreign currency in digital banks and other banks from sample in non-pandemic (NPP) and pandemic periods (PP), Ukraine (source: authors' calculations based on the NBU Data)

\begin{tabular}{|c|c|c|c|c|c|c|c|}
\hline Banks & Period & Mean & St. Dev. & Range & Min & Max & Observations \\
\hline \multirow[t]{2}{*}{ PJSC CB PRIVATBANK } & NPP & -0.011 & 0.015 & 0.050 & -0.040 & 0.010 & 13 \\
\hline & $\mathrm{PP}$ & -0.016 & 0.014 & 0.050 & -0.053 & -0.003 & 10 \\
\hline \multirow[t]{2}{*}{ JSC “Oschadbank" } & NPP & 0.019 & 0.012 & 0.045 & -0.005 & 0.040 & 13 \\
\hline & PP & -0.016 & 0.017 & 0.063 & -0.059 & 0.004 & 10 \\
\hline \multirow[t]{2}{*}{ PJSC “ALFA-BANK” } & NPP & 0.008 & 0.016 & 0.055 & -0.028 & 0.028 & 13 \\
\hline & $\mathrm{PP}$ & -0.025 & 0.019 & 0.066 & -0.067 & -0.002 & 10 \\
\hline \multirow[t]{2}{*}{ PJSC “FUIB” } & NPP & 0.007 & 0.049 & 0.158 & -0.069 & 0.089 & 13 \\
\hline & PP & -0.035 & 0.029 & 0.090 & -0.084 & 0.007 & 10 \\
\hline \multirow{2}{*}{$\begin{array}{l}\text { PJSC "UNIVERSAL } \\
\text { BANK” }\end{array}$} & NPP & 0.048 & 0.041 & 0.126 & 0.000 & 0.126 & 13 \\
\hline & $\mathrm{PP}$ & 0.021 & 0.047 & 0.164 & -0.036 & 0.128 & 10 \\
\hline \multirow{2}{*}{$\begin{array}{l}\text { JSC “CREDIT } \\
\text { AGRICOLE BANK” }\end{array}$} & NPP & -0.007 & 0.017 & 0.061 & -0.037 & 0.024 & 13 \\
\hline & PP & -0.006 & 0.028 & 0.089 & -0.059 & 0.030 & 10 \\
\hline \multirow[t]{2}{*}{ Other banks } & NPP & 0.014 & 0.026 & 0.109 & -0.020 & 0.089 & 13 \\
\hline & PP & -0.018 & 0.015 & 0.051 & -0.048 & 0.003 & 10 \\
\hline
\end{tabular}

\section{Conclusions}

Digitalization had become a worldwide trend with a great impact on every industry. The banking industry is also affected by digitalization in terms of overall globalization. Comparing different digitalization metrics, it could be stated that all of them are showing slightly different values but a similar trend. Looking forward to the set of analyzed countries, it could be stated that DESI and the proposed methodology show a correlation in values. Thus, Lithuania has the highest digitalization value according to both DESI and the proposed methodology. Ukraine got the second result due to a significant growth trend. Poland showed the worst results by both DESI and proposed methodology, but calculated values are not always in line with banking industry development.

Thus, it is obvious that all three surveyed countries are actively involved in the banking sector's digitalization. Traditional banks in the conditions of competition introduce innovations in channels of interaction with clients. Simultaneously, it should be noted that if digital banks are actively represented in all three countries, virtual banking is clearly leading in Lithuania and Poland, compared to Ukraine. This situation is caused by a restraining factor in the form of legislative regulation because Ukrainian legislation has not yet defined the conditions of registration and operation of neobanks. Such projects are forced to be implemented only based on the digital bank as its separate direction. EU legislation in this regard is significantly ahead of Ukraine, so neobanks are a regular participant in the banking sector in both Lithuania and Poland.

An analysis broken down by Ukrainian banks with division into digital and traditional banks showed that digital banks under COVID-19 were better positioned in the segment of household deposits. In particular, their advantages could be observed in the segment of maintaining on-demand deposits in foreign currency and term deposits in foreign currency. One digital bank - Universal Bank - showed the best results in all segments. In general, the influence of COVID-19 turned out to be a challenge for many banks, and digital banks could respond more flexibly to them. In further research, it is necessary to focus on digital banks' features, depending on what form of ownership they have (government, private national, or private foreign), since these factors can have a significant impact under instability.

\section{Disclosure statement}

The authors do not have any competeng financial, professional, or personal interests from other parties.

\section{References}

Bank of Lithuania. (2021). Banking sector. https://www.lb.lt/en/fs-banks

Digital Economy and Society Index. (2020). Digital scoreboard. Data \& indicators. https://digital-agenda-data.eu/datasets/desi

Ehrentraud, J., Ocampo, D. G., \& Vega, C. Q. (2020). Regulating fintech financing: digital banks and fintech platforms. FSI Insights on policy implementation, (27). https://www.bis.org/fsi/publ/insights27.pdf

European Banking Federation. (2019). Banking in Europe: EBF Facts \& Figures 2019. https://www.ebf.eu/wp-content/uploads/2020/01/EBF-Facts-and-Figures-2019-Banking-in-Europe.pdf

Fintech Futures. (2021). Why has Lithuania become a key destination for licensing in Europe? https://www.fintechfutures. com/2019/11/why-has-lithuania-become-a-key-destination-for-licensing-in-europe/ 
Gartner. (n.d.). Definition of digitalization - Gartner information technology glossary. https://www.gartner.com/en/information-technology/glossary/digitalization

Hasan, I., Politsidis, P. N., \& Sharma, Z. (2021). Global syndicated lending during the COVID-19 pandemic. Journal of Banking \& Finance. https://doi.org/10.1016/j.jbankfin.2021.106121

Hess, T., Matt, C., Benlian, A., \& Wiesbцck, F. (2016). Options for formulating a digital transformation strategy. MIS Quarterly Executive, 15(2), 123-139.

InvestLithuania. (2018). Lithuania. The fastest EU entrypoint for your Fintech. https://www.investlithuania.com/wp-content/ uploads/2018/04/Lithuanian_Fintech_2018.pdf

Lumpkin, S., \& Schich, S. (2020). Banks, digital banking initiatives and the financial safety net: Theory and analytical framework. Journal of Economic Science Research, 3(1). https://doi.org/10.30564/jesr.v3i1.1113

Mcintyre, A., Van Der Ouderaa, E., Kirk, P., Bertelsen, A., \& White, K. (2020). Rapid shift to digital banking during COVID 19 accelerating erosion in consumer trust, accenture report finds. https://www.accenture.com/us-en/insights/banking/consumer-study-making-digital-banking-more-human

Monobank. (2020). Pidsumky 2020. https://www.monobank.ua/2020

Morakanyane, R., O’Reilly, P., \& Mcavoy, J. (2020). Determining digital transformation success factors. In T. Bui (Ed.), Proceedings of the 53rd Hawaii International Conference on System Sciences. https://doi.org/10.24251/HICSS.2020.532

Nadkarni, S., \& Prügl, R. (2019). Digital transformation: a review, synthesis and opportunities for future research. Management Review Quarterly. https://doi.org/10.1007/s11301-020-00185-7

Narodowy Bank Polski. (2019). Financial system in Poland 2019. https://www.nbp.pl/en/systemfinansowy/fsd_2019.pdf

National Bank of Ukraine. (2021a). Supervisory data. https://bank.gov.ua/en/statistic/supervision-statist

National Bank of Ukraine. (2021b). Undeniable card market trends in 2020: Online settlements and contactless payments. https:// bank.gov.ua/en/news/all/bezzaperechni-trendi-kartkovogo-rinku-u-2020-rotsi--rozrahunki-v-interneti-ta-bezkontaktni-plateji

NeoBanks.App. (2021a). Neobanks in Lithuania. https://neobanks.app/neobanks/lithuania

NeoBanks.App. (2021b). Neobanks in Poland. https://neobanks.app/neobanks/poland

Niemand, T., Rigtering, J. P. C., Kallmünzer, A., Kraus, S., \& Maalaoui, A. (2020). Digitalization in the financial industry: A contingency approach of entrepreneurial orientation and strategic vision on digitalization. European Management Journal. https://doi.org/10.1016/j.emj.2020.04.008

Prykaziuk, N., Liutyi, I., Pikus, R., Rozhko, O., Versal, N., Erastov, V., Balytska, M., Sholoiko, A., Trygub, O. (2019). Rynok finansovykh posluh. FOP Yamchynsky, Kyiv.

SBSB Fintech Lawyers. (2021). Launching a FinTech business: Why Lithuania is worth considering. https://sb-sb.cz/en/news/ zapusk-finteh-biznesa-pochemu-nuzhno-obratit-vnimanie-na-litvu

Shan, S. (2019). Polish mobile banking app once again voted world's best. https://emerging-europe.com/business/polish-mobilebanking-app-once-again-voted-worlds-best/

Sharma, A., \& Kansal, A. (2014). Technological infovations in banking sector: Impact, behaviour and services. International Journal of Information \& Computation Technology, 4(9), 885-890.

Smith, Zh. M., Lostri, E., \& Lewis, J. A. (2020). The hidden costs of cybercrime. McAfee Report. https://www.mcafee.com/enterprise/en-us/assets/reports/rp-hidden-costs-of-cybercrime.pdf

Stephie, B. (2019). Poland: Challenger digital banks. https://askwonder.com/research/poland-challenger-digital-banks-m9zvsshw8

The Lithuania Tribune. (2021). Start your own neobank in Lithuania and join the digital banking revolution. https://lithuaniatribune.com/start-your-own-neobank-in-lithuania-and-join-the-digital-banking-revolution

Van Veldhoven, Z., \& Vanthienen, J.(2019, June 16-19). Designing a comprehensive understanding of digital transformation and its impact. In Proceedings of the 32th Bled eConference - Humanizing technology for a sustainable society (pp. 745-763). https://doi.org/10.18690/978-961-286-280-0.39

Versal, N. (2019). Finansovi shoky v bankivskii systemi Ukrainy: teoriia, praktyka ta shliakhy adaptatsii, FOP Yamchynsky, Kyiv.

Vial, G. (2019). Understanding digital transformation: A review and a research agenda. The Journal of Strategic Information Systems, 28(2), 118-144. https://doi.org/10.1016/j.jsis.2019.01.003

VMware. (2021). Becoming a digital bank 5 Must-Have it capabilities enabling traditional financial services organizations to drive top-line growth and profitability. https:/www.vmware.com/content/dam/digitalmarketing/vmware/en/pdf/solutions/industry/ financial-services/vmw-ebook-becoming-a-digital-bank.pdf

Wodzicki, M., Majewski, D. A., \& MacRae, M. (2020). Digital banking maturity 2020. https://www2.deloitte.com/content/dam/ Deloitte/ce/Documents/financial-services/ce-digital-banking-maturity-2020.pdf

World Bank. (n.d.). World Bank open data. https://data.worldbank.org 